Viso - Cadernos de estética aplicada

Revista eletrônica de estética

ISSN 1981-4062

$N^{0} 11$, jan-jun/2012

http://www.revistaviso.com.br/

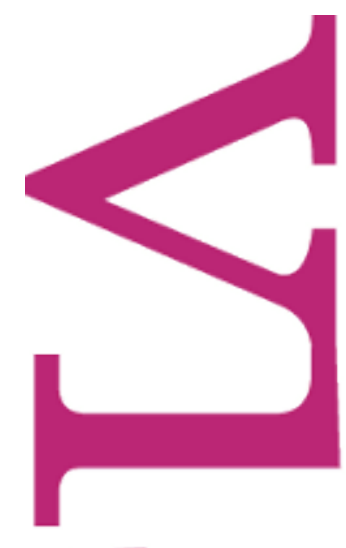

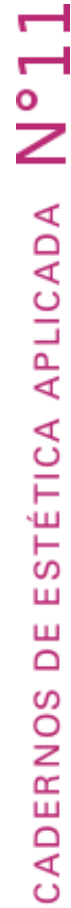
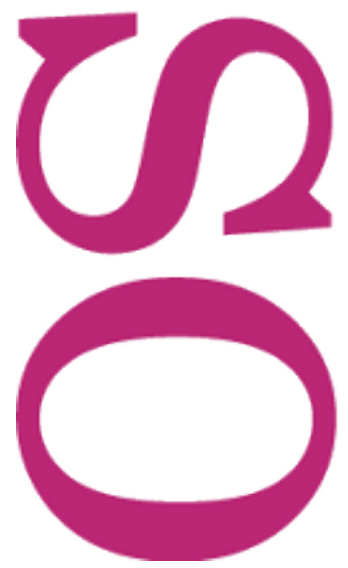

\title{
Variações sobre o tema da modernidade Virgínia Figueiredo
}

Universidade Federal de Minas Gerais (UFMG) 


\section{RESUMO}

\section{Variações sobre o tema da modernidade}

O principal objetivo do presente trabalho é comentar o texto, também publicado neste número da Revista, «Altermodernidade Brasileira» de Luiz Camillo Osório. Tentando acompanhar, de modo assumidamente superficial, a história do conceito de Modernidade, desde sua origem na "Antigüidade platônica", como afirmou Henrique de Lima Vaz, até a nossa contemporaneidade, com a famosa polêmica que dividiu, de um lado, os "Modernos" (Jürgen Habermas) e, de outro, os "Pós-modernos" (Jean-François Lyotard), passando pela Querela dos Antigos e Modernos, pretende-se problematizar a permanência na contemporaneidade, não só filosófica como artística, do conceito de modernidade.

Palavras-chave: Modernidade - crítica - universalismo - herança kantiana

\section{ABSTRACT}

\section{Variations on the theme of modernity}

This paper is mainly a commentary of Luiz Camillo Osorio`s paper « Altermodernidade Brasileira », also published in this magazine. It tries to trace in an inevitably sketchy way the transformations of the concept of modernity, since its origin in "Platonic Antiquity", as asserted by Henrique de Lima Vaz, up to the "Querelle des Anciens et des Modernes" and, finally, to the remarkable polemics that opposed in our days the so-called "Moderns" (Jürgen Habermas) to the "Post-moderns" (Jean-François Lyotard). In doing so, it intends to question the permanence in the contemporaneity of the concept of modernity not only in philosophy but also in the arts.

Keywords: Modernity - critique - universalism - Kantian legacy 
FIGUEIREDO, V. "Variações sobre o tema da modernidade". In: Viso: Cadernos de estética aplicada, v. VI, n. 11 (jan-jun/2012), pp. 173-201.

DOI: 10.22409/1981-4062/V11i/132

Aprovado: 08.08.2012. Publicado: 07.09.2012.

(C) 2012 Virgínia Figueiredo. Esse documento é distribuído nos termos da licença Creative Commons Atribuição-NãoComercial 4.0 Internacional (CC-BY-NC), que permite, exceto para fins comerciais, copiar e redistribuir o material em qualquer formato ou meio, bem como remixá-lo, transformá-lo ou criar a partir dele, desde que seja dado o devido crédito e indicada a licença sob a qual ele foi originalmente publicado.

Licença: http://creativecommons.org/licenses/by-nc/4.0/deed.pt_BR

Accepted: 08.08.2012. Published: 07.09.2012.

(C) 2012 Virgínia Figueiredo. This document is distributed under the terms of a Creative Commons Attribution-NonCommercial 4.0 International license (CC-BY-NC) which allows, except for commercial purposes, to copy and redistribute the material in any medium or format and to remix, transform, and build upon the material, provided the original work is properly cited and states its license.

License: http://creativecommons.org/licenses/by-nc/4.0/ 
Antes de começar, quero agradecer o convite de Pedro Süssekind para participar do Encontro do Grupo de Trabalho em Estética, em seguida, parabenizar toda equipe: Patrick Pessoa, Vladimir Vieira e Bernardo Oliveira, pela organização e especialmente pela escolha do Museu de Arte Contemporânea de Niterói, para a realização do Encontro. O lugar não poderia ser mais adequado e propício a uma reunião que pretende discutir arte e filosofia no Brasil. Perfeito! Obrigada!

Tentando ser sucinta, parto para o texto que coube a mim comentar e aproveito para parabenizar Luiz Camillo pelo texto tão brilhante e bacana sobre a arte e a investigação da difícil, dificílima possibilidade, ou, melhor dizendo, condição da crítica filosófica atual sobre a arte em geral, e, especificamente, a arte brasileira. Luiz Camillo não perdeu o foco e propôs um texto totalmente adequado e inserido na temática do nosso Encontro, «A questão-Brasil». E não só isso, mas um texto que realmente contribui para avançar , ou pelo menos, tentar avançar na reflexão sobre o problema.

\section{TÍTULO}

Como vocês acabaram de ouvir, Luiz Camillo começa por indicar um conceito criado muito recentemente, em 2008, por um teórico e curador francês Nicolas Bourriaud, de «altermodernidade». ${ }^{2}$ Luiz Camillo situa o contexto e a necessidade de novos conceitos para escapar, de um lado, do que ele chamou de "teleologia modernista» (depois teremos de voltar a essa idéia), de outro, da «acomodação relativista da pósmodernidade», com outras palavras: do vale-tudo que parece caracterizar a produção contemporânea da arte. Concordo inteiramente com esse diagnóstico que parece repetir, com ajuda de outros termos, mas não só isso, talvez, novas (e mais complexas, certamente) conjunturas, a "Querela entre Modernos e Pós-Modernos» ${ }^{3}$, que mobilizou parte dos filósofos franceses (emblematizados pela figura de Jean-François Lyotard) e alemães (emblematizados pela figura de Jürgen Habermas) no final dos anos $1970 .{ }^{4}$

Mas, antes de falar desse debate, gostaria de chamar atenção sobre a palavra «altermodernidade». O antepositivo de origem latina «alter», como o dicionário Houaiss nos ensina, está relacionado ao "outro». Trata-se, portanto, de uma alteridade, oposta à identidade. O moderno como o Outro da diferença com relação ao "Nós" da Identidade. Mas, se pensarmos na língua-corrente da filosofia, no idioma alemão, então, "Alter" quer dizer "velho" ou "antigo". É provável que não tenha escapado a você, Camillo, a possibilidade de traduzir, de modo bastante paradoxal, o termo "Altermodernidade" por "Antigamodernidade"... Com isso, unificando (ou desfazendo) a oposição através da qual foram distribuídos os elementos naquela famosa querela, tão importante para toda a história da Filosofia da Arte: Antigos e Modernos, mas também denunciando, por outro lado, a permanência ou nosso retorno recorrente a essa que parece insuperável noção 
de "Modernidade". Proponho que a nossa conversa focalize o problema designado por você mesmo na página 3 como "permanência da Modernidade". Que a gente tente analisar os motivos dessa permanência e, se ainda sobrar algum fôlego, que a gente examine a relação entre modernidade e... Brasilidade, ou, nas palavras de Mário Pedrosa, retomadas por você (pp. 8-9): a nossa "condenação ao moderno". Que a gente tente abordar por que, para nós, a modernidade não foi uma condição, mas uma condenação!

\section{EPÍGRAFE}

Já com relação à epígrafe, Camillo, você vai me desculpar a aspereza com a qual vou reagir! Tenho alguma antipatia pelo "problema" do Roberto Schwarz! Ele sempre me parece o pensador de um pensamento único! Sua única ou principal preocupação é com as classificações, a taxonomia, os lugares apropriados... Quem ocupa qual lugar? Quem é o local? Quem é o universal? Ora, o próprio nome está dizendo que "universal" é qualquer um! Sob a perspectiva do universal, um brasileiro, alemão, chinês, americano, são absolutamente o mesmo: universal! Há muito tempo que, falando de arte brasileira, estamos livres do que ele chamou de "déficits de ex-colônia". Há muito tempo que ninguém (só ele, talvez?) duvida de que Guimarães Rosa, Machado de Assis sejam "universais"... Ora, se o mundo (ou o mercado internacional) demorou a descobri-los, o que importa? O que nos importa? Cedo ou tarde, por uma questão política, de lugar na cena internacional (coisa que depende, como é sabido, de outros fatores: econômicos, sociais e, sobretudo, políticos), eles - os outros, os estrangeiros - acabariam por "descobri-los". Aliás, isso tem cada vez menos importância. Talvez, importância apenas para o mercado! E o problema, para dizer o que penso sinceramente, foi mal colocado. Trata-se de um falso problema, ou anacrônico, como você mesmo, Camillo, apontou, na p. 2 do seu texto, ao se perguntar, cito-o: "como colocar a questão do Brasil sem soarmos anacrônicos, ingênuos e nacionalistas?"

Concordo totalmente com as suas colocações, mas o meu problema aparece quando surge o fantasma dos seus "aliados" - hoje é o fantasma de Roberto Schwarz, e numa correspondência que tivemos há mais tempo ${ }^{5}$, era o de Habermas.... E o perigo do seu (e não de Habermas) conceito "ampliado" ou "hipertrofiado" ${ }^{6}$ de Modernidade... E é engraçado, trata-se de uma pura coincidência, o fato de, tanto antes quanto agora, continuarmos às voltas com esse conceito: a Modernidade. Ainda estamos tentando esticá-lo: Pós-modernidade, Altermodernidade... Espanta-me a sua vigência tanto na arte quanto na filosofia. Ou talvez, não! Quero dizer, talvez, a permanência desse conceito não me espante! Talvez, isso só mostre sua força aparentemente insuperável! Pois, mesmo Pós-modernidade, Altermodernidade não deixam de permanecer tributários à Modernidade. Talvez, o máximo que se possa fazer seja somente tentar analisar as causas ou os motivos daquela duradoura vigência. 
Voltemos para o ponto mais arriscado de seu texto (e para as suas tentativas de solução) e que coincide com o tema do nosso Encontro, «A questão-Brasil». De fato, parece-me que a questão está contaminada a princípio, e é dificílimo escapar da ingenuidade, anacronismo ou nacionalismo, como você mesmo afirmou, apontando os riscos do tema escolhido para o nosso Encontro. Uma das soluções que você propõe, se não me engano, inspirado por Schwarz, é a das relações entre o universal e o local. A tentativa de enfrentar a questão-Brasil sob a perspectiva da relação universal-local, universalsingular. Ok, você busca um Schwarz num momento raro e interessante da dúvida, sobre a "universalidade do universal". Pode-se muito legitimamente perguntar "do que é feito o universal?" Ou "o que o universal contém de universalidade?" Ou ainda, desdobrar o universal na sua relação com o conceito. É inegável que todo conceito tem uma ambição de universalidade, mas será recíproca essa relação? Quero dizer, ou melhor, perguntar: "será que o que é universal na universalidade é o conceito?" Com outras palavras, "o universal nada mais seria senão conceito?" Mesmo reduzindo o universal a conceito, a pergunta sobre o universal não é fácil de responder, nem sequer de um mero conceito empírico... Numa das definições kantianas de conceito, diz-se que é uma "representação daquilo que é comum a vários objetos". ${ }^{7}$ Assim, um conceito empírico, como o de árvore, por exemplo, conteria aquilo que é comum a todas elas: o tronco, os galhos, as folhas, a raiz. Mas, um conceito no caso de uma nação, de um... Brasil, de uma Itália? Que traços comuns deveríamos arrolar a fim de produzir um... conceito de Brasil ou Brasileiro? Escaparíamos dos "tipos", das indesejáveis caricaturas: do malandro, do mafioso? Talvez, a gente tenha de concluir que a questão do nosso Encontro, a questão-Brasil, seja mesmo filosoficamente falando uma falsa questão! Talvez, nosso papel, daqueles que estão tentando refletir sobre a Estética Filosófica no Brasil, não seja outro senão o de dirigir nosso olhar para as obras dos artistas brasileiros.

\section{BH, 13/09/2012}

Sentindo-me pressionada pela fraqueza e até pela falta do instrumental teórico capaz de abordar a questão-Brasil, sou obrigada a abandoná-la e propor que voltemos a nossa atenção para o problema da universalidade, a fim de examinar a sua sugestiva tese da relação entre universalidade e Modernidade. Apesar de a tentativa de atribuir um sentido objetivo (ou conceitual) à universalidade ter se mostrado infrutífera, não vamos recuar, Camillo, pois, nós que lidamos com a arte, estamos habituados a lidar com a dificuldade de não haver conceitos à nossa disposição! $\mathrm{E}$ quem sabe se a irredutibilidade a conceito da brasilidade não é a mesma que caracteriza a arte hoje ${ }^{8}$ (que foi a mesma, aliás, que caracterizou o belo para Kant no longínquo século XVIII)? Quem sabe não apelamos para um possível sentido subjetivo da universalidade? Isso quer dizer que nada de objetivo na obra seria suficiente para classificá-la de "moderna" ou "universal" (se forem mesmo equivalentes esses dois termos). Talvez a noção de "universalidade subjetiva", formulada por Kant no âmbito exclusivo da Estética, possa nos auxiliar bastante na busca de uma resposta à pergunta "o que é universal no universal da arte?" Como todos nós sabemos, Kant chegou a essa fórmula paradoxal no segundo momento da "Analítica 
do Belo", onde ele nos fala de uma "universalidade sem conceito". Se interpretarmos schillerianamente o "universalismo subjetivo", então, ele nada mais significa do que o uso pleno de todas as faculdades (imaginação, entendimento e razão) dos seres humanos, ou, simplesmente, "liberdade", como também o denominou Schiller. Esclarecendo: para Schiller, um dos sentidos da liberdade é o de usarmos todas as faculdades sem prejuízo de nenhuma delas. ${ }^{9}$ Talvez, pudéssemos afirmar que uma obra de arte moderna é aquela que "exige" de nós (de cada um de nós!) a autonomia, que nos obriga a uma atitude livre, não só dos preconceitos, mas também da tradição e da opinião dos outros; que nos convida ao exercício do famoso princípio (crítico) do Esclarecimento, o "Sapere aude!"10 O do pensar por si mesmo! Pois, seria nessa ausência de um modelo a priori onde residiria o aspecto "irredutivelmente singular" desse universal subjetivo.

Poderíamos descrever a situação atual da arte de modo semelhante ao panorama estético da época de Kant, o qual estava dividido: de um lado, as estéticas intelectualistas ou dogmáticas, como a de Alexander Baumgarten, as quais propunham ser o belo um conceito derivado de outros, tais como o de perfeição, simetria ou harmonia; do lado oposto, a tendência empirista ou cética, representada por filósofos como Hume, Hutcheson, Burke, cuja noção de gosto, proveniente unicamente da sensação, tornava-o irredutivelmente singular e não universalizável. Portanto, se a estes últimos convinha o famoso adágio "Sobre gosto não se discute", para os primeiros, a origem intelectual do belo garantia justamente sua universalização, mas, em compensação, perdia-se de vista o âmbito da singularidade. Por conseguinte, o problema kantiano consiste em manter, de um lado, a universalidade do belo, do outro, a dimensão necessariamente singular da experiência artística. Sabe-se que foi a noção de reflexão (e o território crítico aberto por ela) que forneceu a Kant uma alternativa eficaz contra o ceticismo e o dogmatismo estéticos. Também hoje nós nos encontramos diante de duas atitudes que convém combatermos: a da indiferença do equivalente universal que aceita que tudo pode ser arte, à qual poderíamos chamar de «ceticismo (e até cinismo) contemporâneo» de um lado; e, de outro, a da recusa (e até repugnância diante) de toda produção contemporânea como se se tratasse de uma impostura, resumida na fórmula: nada disso é arte! Atitude que poderia ser chamada de «dogmática», uma vez que está orientada por conceitos a priori (melhor seria dizer: préconceitos) e é só em virtude deles que se arroga o direito de excluir e desprezar as obras que, muitas vezes, já estão nos museus ou em bienais etc. Por isso, admiro tanto uma passagemque você escreveu num outro texto: "Para que arte e para que crítica? Encontros e Desencontros". Cito-o:

A crítica é fundamental para se produzir esses deslocamentos, para criar essas passagens, sempre políticas, entre o sem sentido e a criação do sentido, entre tudo poder ser arte e qualquer coisa não ser necessariamente arte. O juízo é uma defesa diante da indiferença do niilismo, que diz que tudo é igual e nada faz sentido. Ajuizar é o compromisso com a produção de diferenças [...]. A crítica, assim como a política, 
procura um consenso, mas vive e habita o dissenso. Em um mundo onde a multiplicidade é a regra, a crítica é um exercício inacabado que impede que as diferenças se anestesiem ou que as identidades se fixem. ${ }^{11}$

Concordo com tudo o que você escreveu aí: com a permanência da crítica (e se além de universalidade, a Modernidade for um conceito equivalente ao da crítica, então, não temos outra saída: continuamos «modernos»); com a definição da crítica (ou do juízo crítico) como «produzir diferenças» que impedem a fixação das identidades. Ora, não passa desapercebido a ninguém a contaminação kantiana do seu vocabulário. O que me leva sempre a perguntar se a atualidade da estética kantiana não reside na sua indeterminação conceitual, na sua impossibilidade de nos fornecer um conceito de belo, a qual pode ser transferida (como nos propôs Thierry de Duve) para a indeterminação (contemporânea) do conceito de arte? Mas alguém poderia objetar que Kant não deixa de nos fornecer uma precisa definição de «belo» como a consciência do livre jogo (ou harmonia) entre as faculdades do espírito. Diante disso, não se pode duvidar, pois, de fato, o belo é um sentimento do acordo entre as faculdades. No entanto, o que nos chama atenção nessa definição é que ela está restrita ao domínio subjetivo e, portanto, incapaz de determinar qualquer critério objetivo. $\mathrm{E}$ isso mesmo que poderia parecer uma carência, um fracasso, na verdade, constitui sua potência, sua ilimitada generosidade, capacitando o juízo sobre a arte a acolher na sua jurisdição sempre em progresso o mais novo e surpreendente objeto. Pois, não podemos nos esquecer de que a atitude crítica é, sobretudo, uma tarefa do sujeito. E o inegável privilégio da perspectiva subjetiva em detrimento da perspectiva objetiva constitui um argumento importante na defesa da atualidade da estética kantiana. Aliás, o outro aspecto a ser lembrado e que é decorrente desse privilégio subjetivo da filosofia de Kant é que toda crítica é também e essencialmente autocrítica.

De acordo com Kant, a segunda máxima do entendimento humano, que caracteriza a faculdade de julgar, é a "de pensar no lugar de qualquer outro" ou "a maneira de pensar alargada". ${ }^{12}$ Hannah Arendt explorou muito o efeito político dessa universalidade ${ }^{13}$ estética (ou simplesmente "subjetiva", como já tivemos a oportunidade de mencionar) e especialmente daquela máxima do juízo. Aliás, creio ser essa uma das principais lições que Arendt extraiu da Crítica da faculdade do juízo, quando diz que Kant nos "ensina a levar os outros em consideração". O sujeito empírico histórico ou o espectador imediato da obra de arte se apequena, deve saber deixar-se um pouco de lado, desinteressar-se de si mesmo, para dar lugar ao outro, para se tornar capaz de pensar na posição de "outros" - assim mesmo no plural, ou então - de um sujeito que é amplo, engrandecido, universal. Será esse o sujeito transcendental? Não sei! Só sei que «empírico», tenho quase certeza de que ele não é. «Empírico» é justamente o "eu" psicológico, imediato, sensível, do qual se deve poder abstrair, para dar lugar ao outro, pois é preciso sair da cena ego-ísta do amor-próprio, que está sempre e somente atento a seus interesses imediatos. Exemplifiquemos: o eu-empírico seria, no meu modo («kantiano») de entender, aquele que está sentindo frio, porque o ar-refrigerado do Museu está muito 
forte, ou que está pensando que são 18:45 e que daqui a 15 minutos o museu vai fechar e ele ainda não teve tempo de ver nem a metade da exposição...

Se não é empírico esse verdadeiro "método" de investigação que é suscitado pelo exercício da reflexão (e da crítica), ele também resiste a conceitos, e, irredutível ao teórico, não se reduz a subsumir fatos (eventos do mundo) a conceitos previamente dados. Diante do que não é um objeto (por isso, mais uma insistência: a de que talvez se trate de uma pré- ou proto-e até in-objetividade), e não é à toa que costumamos designar obra (e não objeto) de arte, o espectador pode ficar um pouco desnorteado, perguntando-se pelas regras a partir das quais ele poderá pensar naquilo que está à sua frente. A originalidade ${ }^{14}$ e o imprevisto que caracterizam por essência aquilo que é moderno, tanto no que diz respeito a acontecimentos históricos (quem previu a "Primavera Árabe"?), quanto a acontecimentos artísticos (de modo ainda mais evidente e freqüente!) tornam caducos os conceitos de que a tradição dispõe e oferta aos espectadores..$^{15}$ Essa resistência que a obra de arte opõe ao conceito, que a tradição insiste em impor a ela, guarda o traço da autonomia, da liberdade que a tornam profundamente política!

Pressinto que a questão da universalidade pode ser colocada com algum proveito para nós, como atenção ao/ ou consideração do ponto de vista dos outros na formação do meu próprio ${ }^{16}$, que deve ser o tanto quanto possível alargado, compreendendo a cada vez um maior número de pessoas. Isso não significa adotar a posição passiva, de assumir de maneira acrítica e simplesmente o ponto de vista do outro. Se isso acontecer, como nos adverte a filósofa, há apenas uma troca de preconceitos: dos meus antigos, pelos do outro, que assumi sem crítica. "Alargar" o seu próprio ponto de vista significa, ao contrário, assumir uma posição ativa. Nem infantil nem egoísta, a crítica assume justamente a posição da maioridade ou do pensamento responsável; e está disposta a reexaminar suas crenças ou opiniões a partir do que foi dito pelo outro. Esse poderia ser o procedimento exemplar de uma subjetividade, digamos assim, em construção, em progresso permanente: do gênio ou do espectador, tanto faz. O que importa é que se trata de uma subjetividade não autoafirmativa, mas autocrítica. O sujeito da crítica é um sujeito em constante mutação.

\section{$\mathrm{BH}, 17 / 09 / 2012$}

A última observação que faria sobre a segunda máxima do entendimento humano - a do pensar alargado ou a do pensar no lugar do outro -, e já me referi antes a ela, é que talvez ela possa constituir um verdadeiro princípio da crítica (em geral, e não apenas da Crítica da Faculdade do Juízo de Kant), constituindo a subjetividade estética de modo distinto das "outras" subjetividades, a moral e a cognitiva. E o que haveria de especial nessa subjetividade estética e que tanto chamou a atenção de Hannah Arendt, a ponto de "estetizar o político" ${ }^{17}$, seria justamente sua essência intersubjetiva. ${ }^{18}$ 
Gostaria de chamar esse princípio (transcendental, estético, político ou histórico?) de "alteridade radical", e esse talvez nada mais seja senão outro nome para designar a "intersubjetividade". Mas se vejo necessidade de cunhar um novo termo é apenas porque gostaria de ressaltar aqui o privilégio que, talvez, só no gosto e no político, o outro, a alteridade assume com relação ao eu mesmo, aos nós próprios. A objeção de que o juízo moral também submete a vontade individual, particular ao assentimento universal e geral aqui não vale, simplesmente porque o teste moral visa algo além dele, ou seja, ele é, digamos assim, meio visando um fim que consiste em comandar uma ação que é totalmente inessencial no caso do político e do gosto, cujo objetivo único e exclusivo seria, digamos assim: julgar, ajuizar, avaliar.

O juízo do gosto ou (quero entender junto com Arendt) o juízo político são um fim neles mesmos. O fato de não desencadearem uma ação imediata no mundo não os torna desprezíveis, irresponsáveis e, muito menos, imorais ou apolíticos. Muito pelo contrário, ousaria dizer que o compromisso deles é até maior, porque é um compromisso com o futuro e não com o presente imediato, o que os tornaria mesmo "arquipolíticos", na medida em que as possibilidades de experiência futura estariam, em último caso, dependentes daquela avaliação. O que vou dizer é bastante óbvio, mas não faz mal, o que quero dizer é que depende do juízo histórico e político o legado da experiência possível. O que os homens que estão por vir vão viver não deixa de estar determinado por aquilo que os homens que vieram antes legaram como experiência possível. E aqui lembro sua frase lapidar (Entrevista concedida ao Caderno Prosa, do jornal O Globo, do último sábado, dia 15/09/2012) e brilhante: "Para que as iniciativas do governo sejam eficazes, é preciso perceber as diferenças entre museu e centro cultural e entre arte e mercado. Dar ao mercado o que é do mercado: agilidade e eficiência. Dar à arte o que é da arte: tempo e experimentação". E eu grifo a "experimentação"! Não só a arte é (deve ser) experimentação, como ela deve legar ao futuro, às novas gerações essa possibilidade. Nosso compromisso é o de melhorar o mundo... Ampliar as possibilidades da experiência.

Deu-nos claramente (um pouco ironicamente é certo) um exemplo disso Stendhal, quando anunciou que está escrevendo para um público que estava a cem anos depois dele. Nada mais estava fazendo senão tentando antecipar-se ao seu espectador-leitor, numa palavra, ao seu "crítico literário", ou melhor, em termos mais genéricos, ao seu crítico, a quem caberia o papel de selecionar as obras de arte que passariam para a "História da Arte", aquelas que iriam tornar-se "clássicas". Transpondo para o ambiente político, os rumos da Revolução Francesa ${ }^{19}$ (como o de qualquer outro acontecimento histórico) dependeram, de maneira imponderável, da sua recepção (o que quer dizer senão o ajuizamento? Apropriação?) pelos seus contemporâneos. É por isso que se temos motivos de sobra para louvar a atitude kantiana de entusiasmo em favor dos princípios de igualdade, liberdade e fraternidade, também temos motivos de sobra, e, nesse caso, infelizmente, a nossa decepção com a irreparável, imperdoável adesão de 
Heidegger ao Nazismo. Em ambos os casos, tratou-se somente/apenas de um juízo histórico, político... Numa palavra: crítica!

$\mathrm{BH}, 18 / 09 / 12$.

Caro Camillo,

acho que esta é minha última carta! Sinto ainda o ímpeto de dar consistência à objeção ao que eu chamei, logo no começo da nossa correspondência, de "problema-Schwarz". E essa objeção passa pela importante noção hölderliniana de "nationel" e pela não menos importante reflexão que Lacoue-Labarthe fez sobre ela, cunhando, por sua vez, o inédito termo de "mimetologia" que, no meu entender, serviu como uma espécie de "lógica da história" que visava substituir a "lógica dialética" (hegeliana). Portanto, farei um imenso desvio, que julgo necessário, pois ele deve acabar por esclarecer também outra expressão sobre a qual não retornamos, a de Mário Pedrosa, da nossa "condenação ao moderno". Ora, como você haverá de constatar, terei de dar uma volta muito grande para concluir com a descoberta de uma lei essencial da cultura que seria a da "(des)apropriação". Retomo a seguir alguns parágrafos de um texto "A permanência do trágico", que escrevi em 2007. ${ }^{20}$

Para se atingir a concepção hölderliniana de História, é preciso fazer um breve desvio pela querela ainda vigente na Alemanha do século XVIII, entre os Antigos e os Modernos, e a concepção algo inédita e original que o poeta inventou sobre os Gregos. Beda Allemann explicita a estranheza, frente a seus contemporâneos, da concepção "oriental" da Grécia hölderliniana. Em seu ensaio, não à toa, intitulado "Hölderlin entre les Anciens et les Modernes", ele diz:

No último período de seu trabalho, [Hölderlin] renuncia [...] àquilo que era comum entre os seus contemporâneos, e que ele próprio havia professado nas suas primeiras tentativas, isto é, olhar a Antigüidade como a época da juventude da humanidade civilizada em geral (uma humanidade considerada mais ou menos universalmente a partir de um centro que não é outro senão a Europa), e correlativamente considerar a época contemporânea como a velhice cada vez mais prosaica do que havia sido a juventude mesma. ${ }^{21}$

Para Lacoue-Labarthe, no entanto, Hölderlin teria ido mais longe do que apenas rejeitar a Grécia infantil e sua imagem nostálgica, ele teria apontado para sua possível inexistência. É como ele se refere, em "Hölderlin e os Gregos", insinuando que o poeta, na sua tentativa de formular o princípio de uma arte moderna, teria se dado conta da impossibilidade de uma imitação dos Gregos, convencido de que "a Grécia, como tal, a 
Grécia ela mesma, não existiu"; talvez nunca tenha existido ou, quem sabe, Hölderlin tenha descoberto que a Grécia era "pelo menos dupla, dividida - quase rasgada. E que aquilo que conhecemos dela, que é talvez o que ela foi ou o que manifestou de si mesma, não é o que ela realmente era - o que, em contrapartida, talvez nunca tenha aparecido". ${ }^{22}$

Mas a leitura lacoue-labarthiana de Hölderlin não pára aí, nessa originalidade da Grécia hölderliniana (da "Grécia dupla, dividida ou quase rasgada"), pois eu diria que o interesse de Lacoue-Labarthe é, em última análise, o mesmo do poeta, i.e., mais do que uma reflexão sobre os Gregos, quer-se saber o que são os Modernos, e de que modo aquela Grécia ferida não acabaria por afetar também a possibilidade da arte moderna. Resumindo bastante, Lacoue-Labarthe concluiria que a excentricidade do poeta, com relação aos seus contemporâneos, estaria, não somente no seu conceito sobre os Gregos, mas no modo, mais profundo e rico de conseqüências, como reformulou a querela entre os Antigos e Modernos. Repetindo, a grande contribuição do poeta, para Lacoue-Labarthe, seria o modo inédito como Hölderlin concebeu a querela entre Gregos e Antigos, quer dizer, como uma filosofia da história ou, nos termos que Ihe interessam, como uma mimetologia. Mas a compreensão desse caráter filosófico da poética de Hölderlin nasce, ou, pelo menos, consolida-se ${ }^{23} \mathrm{com}$ a interpretação heideggeriana, que foi a primeiríssima a vislumbrar o alcance, digamos assim, "extrapoético" daquela poética.

Poder-se-ia então concluir que o aspecto comum às leituras, de certo modo, herdeiras da interpretação "filosófica" de Heidegger, é a ênfase na construção inaudita de história que Hölderlin nos oferece? - Talvez. E mais do que isso, elas seriam sensíveis à questão heideggeriana que, formulada um pouco grosseira e abruptamente, consistiria em, assumindo essa lógica histórica ou poética de Hölderlin confrontar-se com a lógica dialético-filosófica de Hegel? Atentos à importância e à originalidade daquela reflexão hölderlininana sobre a história, os autores foram tentando decifrá-la segundo nomes ou perspectivas que jamais coincidem totalmente: Beda Allemann chamou-a de "dinâmica" ou "ultra-dialética", enquanto Lacoue-Labarthe a designou "mimetológica", "hiperbológica" ou simplesmente "trágica". ${ }^{24}$ Com outras palavras, o que me permite afirmar a permanência do trágico é que esse princípio "mimetológico" ou "trágico" (como o revela a leitura que Lacoue-Labarthe faz de Hölderlin), ou simplesmente "historial" 25 (Heidegger), o qual, em oposição ao princípio histórico-dialético de Hegel, é essência do movimento da história, talvez ainda continue em vigor.

Essa mimetologia ou filosofia da história consistiria numa impossibilidade da síntese nostálgica (ou dialética ${ }^{26}$ ) entre a natureza e a arte. Em Hölderlin, há uma espécie de intransigência ou radicalidade extrema que não permite ao impulso formador [Bildungstrieb], que vai da natureza à arte, dos homens aos deuses, encontrar um descanso, um momento de resolução apaziguante. Excetuando-se o fato de partirem de pólos opostos, as tendências culturais, dos Antigos ou dos Modernos, não seriam 
essencialmente distintas. Em outras palavras, a origem da cultura (pouco importa se dos Gregos ou dos Hespéricos) é trágica. Na verdade, essas tendências estariam sujeitas àquilo que Lacoue-Labarthe chama de uma "dobra interna", que duplicaria, a cada vez, um dos termos envolvidos na oposição (Antigos e Modernos, Natureza e Arte) abrindo uma ferida inaugural na essência de toda cultura, a qual, traduzida nas categorias de "próprio e impróprio", redundaria na descoberta de uma lei essencial da "(des)apropriação". ${ }^{27}$ Isso significa que o movimento interminável a que toda cultura está submetida, o movimento de apropriação ou disso que Hölderlin chamava de "nationel", natal ou nativo, só se instala "sob a condição de ter passado pela prova de sua alteridade e de sua estranheza". ${ }^{28}$

Essa apropriação da alteridade, do estranho (do estrangeiro) como essência do "nationel" não explicará talvez por que Pedrosa falava em "condenação" ao invés de "condição"?

P.S. $-\mathrm{BH}, 6 / 10 / 2012$.

\section{Caro Camillo,}

como a Revista nos concedeu generosamente (ou será, na verdade, de modo martirizante?) mais tempo, resolvo escrever este P.S. à moda benjaminiana, i.e., com três citações. Acontece que o prazo estendido me forneceu a oportunidade de ler simultaneamente os seguintes trechinhos sobre brasileiros e alemães que refletem apenas a dificuldade pressentida desde 1801, pelo poeta Hölderlin, na carta escrita a seu amigo Böhlendorf e que está na epígrafe desta minha resposta:

1) Mário de Andrade: "abrasileiramento do brasileiro não quer dizer regionalismo nem mesmo nacionalismo $=$ o Brasil pros brasileiros. Não é isso. Significa só que o Brasil pra ser civilizado artisticamente, entrar no concerto das nações que hoje em dia dirigem a Civilização da Terra, tem de concorrer pra esse concerto com a sua parte pessoal, com o que o singulariza e individualiza, parte essa única que poderá enriquecer e alargar a Civilização". ${ }^{29}$

2) Heinrich Heine: "No que concerne aos alemães, não precisam nem da liberdade, nem da igualdade. São um povo especulativo, ideólogos, pensadores e devaneadores, sonhadores que vivem unicamente no passado e no futuro, mas que não têm presente. Ingleses e franceses têm presente, para eles todo dia tem sua luta, seu embate, sua história. O alemão nada tem por que possa lutar e quando começou a suspeitar que havia coisas, cuja posse era desejável, seus filósofos previdentes lhe ensinaram a duvidar da existência de semelhantes coisas". ${ }^{30}$

3) Ainda Heine: "Não falemos mal dos alemães. Embora sejam sonhadores, havia entre eles quem sonhasse sonhos tão belos que eu não os trocaria pela realidade desperta de 
nossos vizinhos [...] Senhor, não deboche dos nossos sonhadores, pois de vez em quando dizem coisas maravilhosas no sonho, como sonâmbulos, e sua palavra se torna semente de liberdade. Ninguém pode prever o futuro das coisas. Se um dia, Deus nos livre, a liberdade desaparecer do mundo inteiro, um sonhador alemão a redescobrirá em seus sonhos". ${ }^{31}$

\section{Resposta de Luiz Camillo Osorio - Filosofia PUC-Rio}

A resposta foi iniciada em 23/9/2012 e terminada em 7/10/2012, mas teve várias entradas ao longo destas duas semanas, como se poderá notar nas referências às datas e a coisas que fui lendo e trazendo irresponsavelmente para a conversa. Gostaria também de me desculpar por não ter tido tempo de desenvolver com mais rigor e cuidado acadêmico, usando mais e melhores citações de suporte aos meus argumentos. Se fizesse isso não acabaria. São insinuações e intuições que ficam lançadas ao debate.

\section{Oi Virginia}

Antes de começar queria agradecer muito seus comentários. É realmente um luxo ter esta interlocução. Como falava naquela primeira parte de nossa conversacorrespondência em 2008, tentar responder às suas questões é mais um esforço de tentar esclarecer para mim mesmo alguns pontos que proponho e que são ainda tateantes e nada claros, a saber: a questão do moderno e sua permanência, a questão Brasil na arte contemporânea (brasileira e não brasileira) e o sentido de se manter alguma pretensão de universalidade depois da crise dos grandes relatos. Enfim, muitos temas espinhosos e que demandam enorme cuidado reflexivo para não descambar para o nostálgico ou o anacrônico.

Queria começar pelos meus aliados de ocasião - Habermas e Schwarz. O primeiro, identificado por você naquela primeira correspondência por conta de minha defesa de uma Modernidade como algo definitivamente inacabado. Agora o crítico paulista, por conta da epígrafe que utilizei e que reclama pela manutenção do binômio, mantido como uma tensão, entre universal e local. Queria frisar que, por mais que os tenha trazido para perto, não os vejo como aliados. Creio que se trata mais de dividir um conjunto de questões comuns, mas pensando-as de modo diferente. No caso do Habermas, como já falamos antes, não me interessa a leitura dele, não me entusiasma a maneira como ele quer salvar a Modernidade, mas apenas o diagnóstico de que há algo na modernidade a ser repotencializado: para mim é a dimensão experimental que fica como marca do moderno a se insistir. Em vez de querer retomar a Modernidade para realizá-la ou acabála, o que mais me interessa é preservar o inacabamento como algo intrínseco ao moderno. Este definitivamente inacabado do Moderno retoma indiretamente o Grande Vidro do Duchamp, a apropriação do acaso, da contingência, como aquilo que atravessa o ato criador e o faz sempre irrepetível e indeterminável, ou seja, inapreensível conceitualmente. Este inacabamento do moderno é sua propriedade experimental. 
Como pensar esta experimentalidade sem a crença no futuro como horizonte aberto de possibilidades? Como pensar a experimentação fora da teleologia progressista do modernismo? É aí que acho interessante discutir o moderno depois do modernismo. O Baudelaire é fundamental, pois ao mesmo tempo em que experimentava com a linguagem poética, deslocava as normas e os lugares da poesia, mantinha enorme repulsa ao progresso, fazendo do belo sempre extravagante, sempre contingente, sempre trágico, uma promessa de felicidade, de iluminação profana, no presente, no meio da multidão e do dissenso. Modernos depois do modernismo são Baudelaire, Duchamp, Oiticica e mesmo Lyotard, não o Habermas - que me parece mais modernista - com sua expectativa de uma racionalidade das ações comunicativas, sua ansiedade em reduzir as diferenças agônicas a um horizonte consensual. O moderno depois do modernismo talvez seja resgatar ou redescobrir o que tenha sido perdido entre Kant e Hegel, como intuíra o Fernando Pessoa! O frescor e a crítica do presente sem o determinismo da máquina historicista.

Não quero mesmo ficar preso a denominações ultrapassadas. Meu interesse pelo moderno é o interesse crítico pelo presente.

Quanto ao Schwarz, o que me levou a usá-lo como epígrafe foi a preocupação apontada nesta passagem de uma disjuntiva empobrecedora entre o universal e o local. Como se a afirmação universalista do Machado, sua voz literária descolada de certa especificidade brasileira, inviabilizasse qualquer pretensão de vinculá-lo a ela. Em que medida a universalidade do Machado, do Oiticica, da Clarice, do Glauber, do Guimarães, da Lygia Clark, do Tunga, do Nuno, do Neto, entre outros, é capaz de produzir deslocamentos de entonação local no próprio universal? Esta universalidade simbólica da literatura, da arte, é sempre invenção de um modo de universalizar-se, de ser junto com o outro, um gesto detonador de novas relações e novas formas de articular sentidos compartilháveis. Ao mesmo tempo, esta invenção não pode ser demonstrável, fixada em modelo normativo, apenas provado (como provamos uma ideia na língua, para citar Baudelaire) numa experiência que traz o outro para o horizonte de compartilhamento sem reduzi-lo à identidade do mesmo. A universalidade pretendida pela experiência da arte é a do qualquer um. Não se trata de um igual, mas de um outro qualquer que pode vir a compartilhar o meu sentido e o meu mundo (universalidade subjetiva). Não se trata de um universal que assume a necessidade de todos concordarem comigo (universalidade objetiva). Talvez seja uma universalidade fraca, hipotética, pressuposta, possível, antes que atual. O que interessa nela é que se deixa abrir à diferença e à multiplicidade e não é a afirmação de uma verdade indiscutível e sempre idêntica a si mesma.

Adorei a sua discussão a respeito da mentalidade alargada kantiana e da sua apropriação pela Hannah Arendt. Acho esta leitura que você faz muito perspicaz e iluminadora. Este sujeito que se põe no lugar do outro, fundamento do juízo estético desinteressado, não é o sujeito empírico, meramente sensorial, mas um sujeito que se 
projeta além da empiria, do imediatismo da experiência. Apostar nesta possibilidade é apostar na nossa capacidade de imaginar formas de ser no mundo não determinadas. É a imaginação não se submetendo às determinações do já constituído e refletindo formas possíveis e ainda não atuais. Acho excelente a sua passagem que diz: "O sujeito empírico histórico ou o espectador imediato da obra de arte se apequena, deve saber deixar-se um pouco de lado, desinteressar-se de si mesmo, para dar lugar ao outro, para se tornar capaz de pensar na posição de 'outros' - assim mesmo no plural, ou então - de um sujeito que é amplo, engrandecido, universal”. O importante aí, a meu ver, é que esta abertura ao outro que projeta uma universalidade possível parte de algo sentido, portanto de subjetivo, mas sem se fechar na subjetividade. Gostaria de desdobrar isso na relação entre local e universal, na afirmação de uma dimensão local que não se prende a um princípio nacional, mas a um devir singular que pode ser compartilhado por outros, tomado pelo outro como seu também. Daí eu falar também da possibilidade de um Brasil que vai além do sujeito empírico brasileiro. Não se trata de uma certificação de passaporte, mas de um tornar-se outro que tem no Brasil um modo singular de ser creio que isso também acontece no que diz respeito às possibilidades de tornar-se, por exemplo, italiano, japonês ou australiano.

Acabo de ler no avião (dia 01/10/2012) uma entrevista com o Tunga, na revista da TAM de setembro-outubro de 2012, em que ele apontava - depois de mencionar sua formação no estrangeiro, a importância das viagens, da convivência com a diferença - para o fato de ter "percebido que não deixava de trazer debaixo dos meus pés a poeira do Brasil, um país tão rico, tão diverso, tão cruel e tão difícil, mas que, ao mesmo tempo, é tão lindo." Temos que nos esforçar para pensar sobre esta poeira como o que fica imperceptível, que fica na indecisão entre o não-ser e o ser outro. Nesta indefinição fica também a abertura para a construção de um sentido comum, uma projeção de universalidade, feita de várias poeiras, constituindo um comum heterogêneo e plural. Vejo a arte e sua abertura simbólica, sua aposta no "como se", como o lugar em que ainda podemos pensar sobre esta comunidade de diferentes que se antagonizam, se misturam e se multiplicam.

Para terminar citando um novo aliado, Caetano Veloso, retiro de seu artigo publicado hoje (O Globo, 07/10/2012, Segundo Caderno, pag.2) uma frase enigmática que aponta nesta mesma direção que tenho pretendido abordar nossa altermodernidade: "estamos ainda na indefinição de nossa mensagem sem que nos convençamos de que não teremos mensagem relevante". Acreditar desconfiando numa mensagem indefinida proferida a partir de um Brasil que está "fora da roda dos que falam e significam", mas que ainda sonha em ser relevante na sua irrelevância. Resume-se aí um Brasil, uma promessa, uma experimentação de universalidade e uma desconfiança intrínseca a respeito desta promessa e deste Brasil.

Fico por aqui, mas a nossa conversa continua. 
$\mathrm{BH}$, algum dia de 2008

\section{Olá Camillo}

Demorei mas aqui estou para comentar o seu texto. ${ }^{32}$ Espero que você receba esta mensagem. O meu e-mail da FAFICH/UFMG está fora do ar desde sexta-feira...

Não sei se concordo com a "intenção", diria, do seu texto. Pelo que entendi, você pretende estendera noção de "moderno" a ponto de ela compreender a "coleção contemporânea de arte" que estava exposta no Museu de Arte Moderna em SP...

OK! Vocêpode até estar amparado nessa intenção de hipertrofiar a noção de moderno.

Recentemente, dei um curso sobre "Modernidade e Pós-modernidade", e, por causa dele, estive às voltas com uma extensa (para lá de extensa) bibliografia sobre a Modernidade. Entre outras, há umlivro de um famoso professor de filosofia (aqui para nós) da UFMG que já morreu, o pe. Henrique de Lima Vaz, o livro se chama Raízes da Modernidade. ${ }^{33}$ Então, nesse livro, o pe. Vaz estende para trás o conceito de Modernidade na filosofia... Ele o encontra lá em Platão...

Transcrevo aqui para você um trechinho do meu curso que começou com uma definição

do Vocabulaire d'esthétique ${ }^{34}$ :

O conceito de "moderno"... data do século $\mathrm{V}-\mathrm{VI}$, quando apareceu a palavra latina "modernus". É o momento no qual o pensamento europeu toma consciência de viver uma profunda e irreversível mudança, e no qual todo um período da história aparece como revirado/transformado. O adjetivo francês "moderne" transcreve "modernus" e o encontramos no final da Idade Média. Quanto ao substantivo "Modernidade", ele aparece em meados do século XIX (Baudelaire, Théophile Gautier). A palavra "moderno" foi empregada pela primeira vez em fins do século $\mathrm{V}$, para marcar o limite entre o presente, que há pouco se tornara oficialmente cristão, e o passado romano-pagão. Com conteúdos variáveis, a "Modernidade" sempre volta a expressar a consciência de uma época que se posiciona em relação ao passado da Antiguidade, a fim de compreender a si mesma como resultado de uma transição do antigo para o novo. Isso não vale apenas para o Renascimento, com o qual se iniciam, para nós, os tempos modernos. Os homens também se consideravam "modernos" na época de Carlos Magno, no século XII, e na época do lluminismo - ou seja, sempre que na Europa se formava a consciência de uma nova época mediante uma renovada relação em face da Antiguidade. Apesar disso, a antiquitas serviu como modelo normativo, digno de ser imitado, até a famosa querela dos Modernos com os Antigos, isto é, com os seguidores do gosto da época clássica na França de fins do século XVII. Apenas com os ideais de perfeição do lluminismo francês, apenas com a ideia, inspirada pela ciência moderna, de um progresso infinito do conhecimento e de um avanço rumo ao aprimoramento social e moral é que, aos poucos, vai-se quebrando o fascínio exercido pelas obras clássicas do mundo antigo sobre o espírito de toda modernidade. Finalmente, a Modernidade, opondo ao clássico o romântico, busca um passado próprio numa Idade Média idealizada. No decorrer do século XIX, este romantismo libera aquela 
radicalizada consciência da Modernidade, que se desprende de todos os laços históricos, conservando no todo apenas a oposição abstrata à tradição, à história.

Num outro livro, Escritos de filosofia III, esse mesmo Pe. Vaz afirmou a equivalência entre Modernidade e a própria filosofia! Por isso, ele a localizou na Grécia do século VI a.c e defendeu que esse sentido propriamente filosófico do termo teria sido bem anterior a seus outros usos: político, social, antropológico! ${ }^{35}$ Para ele, o moderno não seria mais do que uma leitura do tempo pela razão filosófica ${ }^{I_{36}}$

Você tem toda razão de dizer que as definições que você encontrou de "Modernidade" como "purificação dos meios expressivos" (creio ver aía definição de Clement Greenberg, não?), por exemplo, são precárias... De fato,a Modernidade não pode ser apenas um critério para classificar um gênero, delimitar uma fronteira cronológica... Como você, não gostaria de ver perdido um valioso sonho utópico que talvez seja inerente à Modernidade...

Apesar de não concordar com quase nada que Habermas escreve em seu livro $O$ discurso filosófico da Modernidade ${ }^{37}$, sobretudo seus comentários a pensadores como Nietzsche, Heidegger, Derrida, os quais, na maioria das vezes, me parecem injustos, não posso deixar de mencionar uma [dentre muitas definições: "racionalismo ocidental" (Weber) ${ }^{38}$, "época orientada para o futuro, que está aberta ao novo que há de vir" (Schelling) ${ }^{39}$, "aquilo que um dia será clássico" (Baudelaire) ${ }^{40}$, "relação entre instante e eternidade" (Baudelaire/Benjamin) ${ }^{41}$ ] definição que Habermas introduz do seguinte modo: "Nem Hegel nem seus discípulos diretos, à esquerda ou à direita, jamais questionaram as conquistas da Modernidade, de onde os tempos modernos tiraram seu orgulho e consciência de si. A época moderna encontra-se, sobretudo, sob o signo da liberdade subjetiva". ${ }^{42}$ Temos de concordar com Habermas que, de fato, a liberdade subjetiva é uma conquista irreversível e que propiciou profundo orgulho nos modernos. E, até hoje, sua perda significa humilhação. Talvez, a necessidade e o valor da arte residam exatamente aí no inegável elo que liga a arte à liberdade subjetiva (não só de modo mais evidente no caso do artista, mas também do espectador, cuja imaginação caminha livremente).

Se, por um lado, constatamos a complexa multiplicidade do conceito de Modernidade na Filosofia, sempre me pergunto se, do lado do que poderíamos chamar de "Discurso artístico da Modernidade", o moderno não teria um sentido muito mais restrito e até cronológico, daquilo que precede o contemporâneo... Sou ignorante em termos de História ou Crítica de Arte, mas chego a duvidar que o conceito de Modernidade possa ter essa complexidade que o vimos atingir na Filosofia. Apesar de discordar totalmente desse herdeiro avarento do universalismo kantiano (logo voltarei a essa observação), não podemos esquecer que o extenso e erudito mapa que Habermas desdobra diante de 
nossos olhos no "Discurso filosófico da Modernidade" trata exclusivamente do "filosófico", como ele mesmo se apressa a nos prevenir, desde o Prefácio de DFM, de que aquelas lições "não tratam do modernismo na arte e na literatura". ${ }^{43}$

De fato, tratando-se de arte, talvez a gente possa atribuir ao próprio Habermas o que ele afirmou de maneira injustificada de Heidegger: em primeiro lugar, uma "compreensão classicista da arte", em seguida, "que ele fora muito pouco influenciado pelas experiências genuínas da arte de vanguarda"44 (Habermas cita Oskar Becker para definir Heidegger). O que pretendo deixar claro é que, apesar de Habermas ter feito uma extensa e erudita pesquisa filosófica sobre a Modernidade, isso não impediu um sério "déficit" nas suas posições sobre a arte, i.e., no que diz respeito a um possível "Discurso artístico da modernidade". Portanto, talvez seja necessário distinguir "Modernidade artística" e "Modernidade filosófica". Apesar de sua profunda erudição filosófica, ela não foi suficiente para tomar o partido (no que diz respeito à arte) das vanguardas e ele manteve - pelo menos na discussão com Lyotard - um ponto de vista retrógrado (contra o que Lyotard defendia: "experimentação"). Nesse sentido, ele acaba por ter uma "compreensão classicista da arte", semelhante à que ele condenou em Heidegger.

Finalmente, não consigo ficar quieta diante do imenso mal-entendido que constitui a conclusão de Habermas a respeito da interpretação heideggeriana da arte. Cito mais uma vez o DFM: "Daí ser-lhe (a Heidegger) tão fácil nivelar o 'fenômeno estético' e equiparar a arte à metafísica". ${ }^{45}$ Ora, ao invés de "equiparar a arte à metafísica", "nivelar o 'fenômeno estético", eu diria, ao contrário, que Heidegger estava tentando "superar" (não mais num sentido dialético, hegelianamente falando...), ir com a Arte para além da Metafísica. Senão, como entenderíamos a frase lapidar (mas, programática) que está no livro "Introdução à Metafísica"? "(Enquanto) Hegel olha para trás e fecha um ciclo, Hölderlin olha para frente e abre outro ciclo"? ${ }^{46}$ Para concluir no sentido diametralmente oposto ao de Habermas, basta que a gente reflita de maneira superficial sobre as implicações dessa pequena frase: em primeiro lugar, Heidegger situa Hölderlin não só numa posição equivalente (em termos filosóficos) a Hegel, mas até mesmo em posição de superioridade, no lugar de "abertura" de um novo ciclo; além disso, ele aponta que a culminância do pensamento talvez não seja mais filosófica, já que o ciclo hegeliano "se fechou", mas sim poética, uma vez que, do outro lado da linha, Hölderlin aparece com sua "dialética" feita sob o registro da interrupção, da cesura e da irresolução! Essa "dialética" a que se deve chamar de "trágica", porque ela é paradoxal e não é obediente aos limites impostos pela lógica tradicional que se horroriza com a contradição.

Se chamei de avarenta a herança que Habermas reclama do "universalismo kantiano" é porque considero seu (de Habermas e não de Kant) universalismo excludente! Ele quer reivindicar para si (e somente para si) o direito à herança de Kant! Dessa herança, ele autoritariamente quer excluir filósofos e pensadores que, apesar de ele não aceitar, igualmente pretendem estar "sucedendo" Kant. Toda a filosofia contemporânea francesa, de Derrida, passando por Lyotard, Foucault se dedicou à leitura de Kant, sobretudo da 
Crítica da faculdade do juízo e, portanto, sempre reivindicou também legitimamente essa herança crítica! Diria que para todos esses filósofos franceses contemporâneos a posição crítica que eles aprenderam com Kant tornou-se definitiva, irrevogável e insuperável! Nessa lista, ainda faço questão de incluir Heidegger! Sempre brinquei com meus alunos que Heidegger se considerava um filho de Nietzsche e neto de Kant, assim nessa filiação direta! Precisamos apenas tirar o universalismo kantiano das mãos sovinas de Habermas! Universalizar prodigalizando (incluindo, e não excluindo como faz Habermas o tempo todo!), se possível, a todos, a herança kantiana...

Mas, voltemos a atenção para as próprias obras de arte. Seria possível distinguir o moderno do contemporâneo? Será que devemos chamar Duchamp e Wahrol de "modernos"? Nesse caso, onde colocaremos Manet, Van Gogh e os impressionistase os expressionistas abstratos? Talvez, esteja sofrendo daquela patologia schwarziana... De querer fazer classificação, taxonomias a todo custo! Mas, de qualquer modo, é inegável a diferença entre Manet e Van Gogh, de um lado, e Duchamp e Warhol, de outro... Mesmo que a teoria do gênio tenha revogado em parte o princípio predominante que tinha orientado a arte desde sempre, que é a mimesis ${ }^{47}$ não se pode reconhecer ainda, no caso dos impressionistas, "modernos por excelência", algum diálogo possível com a mimesis? Mesmo que fosse para subvertê-la! Insurgir-se contra ela! Até quando Pollock derruba a tela no chão, num gesto de irrevogável rebelião, não deixo de considerar que, mesmo sendo gesto de negação, recusa e contestação, desenrola-se um diálogo com a imitação. ${ }^{48}$

A arte contemporânea não terá nascido de outro princípio? O da necessidade de incluir na própria obra uma questão (problema ou pergunta) sobre sua origem ou essência? Não será esse um traço específico e exclusivo da obra de arte contemporânea? A meu ver, uma das teses importantes de Danto $^{49}$ sobre a arte contemporânea ${ }^{50}$, ele a enuncia ao examinar os "pares indiscerníveis", de um lado, de Duchamp (Fountain ou as Pás de neve), de outro, de Warhol (a Brillo Box). Repetindo: a arte contemporânea teria de absorver em sua própria estrutura uma dimensão filosófica, reflexiva. É apelando para a consciência de uma diferença que, ainda no meu modo de ver, Danto "resolve" o problema dos "pares indiscerníveis". Mas qual será mesmo a diferença entre o objeto que está na realidade (no supermercado, na loja de materiais de construção etc.) e o que tem, sendo arte, o "direito" de estar exposto nas galerias ou nos museus?

Incluir uma pergunta (de caráter talvez essencialista e, portanto, filosófico) se ela tem o direito de reivindicar seu nome como "arte" talvez seja o mesmo que se assumir como pura experimentação. OK! Você vai me dizer que colocou a experimentação dentro do "moderno"... De fato, no seu texto, você faz essa associação. Mas, eu prefiro dizer que a arte que radicalizou o princípio da experimentação foi a contemporânea ou pós-moderna (e não moderna). Que é ela - a arte contemporânea ou pós-moderna - a que vive na fronteira máxima entre a arte e a não-arte... Não temo o nome "pós-moderno", apesar de todos os quiproquós que o envolveram! 
Concluindo agora: na filosofia, a Modernidade é um conceito que está posto, se o pe. Vaz tem razão (e eu não tenho erudição suficiente para encararuma "afirmação" dele...), desde a Antiguidade.A querela entre Antigos e Modernos parece que é antiquíssima na história da filosofia... Mas, será que para a história da arte é interessante essa ampliação (ou hipertrofia) do conceito de Modernidade? Isso sem voltar a mencionar o debate entre Habermas e Lyotard... Há uma diferença muito grande entre o universalismo kantiano que Habermas defende ao afirmar que "a Modernidade ainda é um projeto inacabado..." e a tese que pretendo defender da atualidade da Estética kantiana. E eu precisaria de muito mais de uma carta para explicar minhas diferenças com relação a Habermas... Não estou, nunca estive identificada comHabermas... E estou mesmo convencida de que a cisão que ele impôs entre os "herdeiros de Kant", separando, na filosofia contemporânea, franceses, de um lado, alemães, de outro, não fez bem a ninguém! Tenho umas conversas interessantes com o pessoal da Arquitetura da UFMG, eles defendem frequentemente a "pós-modernidade"... Acho que foi, sobretudo, nessa arte, a arquitetura, onde a "Modernidade" apresentou sua faceta menos democrática, apesar de sua fachada pretensamente igualitária... Ou seja, é urgente você vir a $\mathrm{BH}$, não só para visitar Inhotim, como para participar das nossas discussões.

Um grande abraço e parabéns! De qualquer modo, seu texto é maravilhoso e tem uma tese forte, apesar de eu não concordar muito com ela.

Virginia

P.S. Gostaria muitíssimo de ter em mãos seu livro sobre a Crítica... É isso que ando estudando agora.

\section{Resposta de Luiz Camillo}

Bem, Virginia, vou tentar encarar uma resposta, por-me na direção de uma explicação sobre o meu ponto. Por-me aqui na direção é o que me interessa, pois esta questão é aberta para mim, algo que ainda não se constituiu como uma compreensão apropriada. Não sei se me interesso por estas explicações que voltam à Grécia, ou à Idade Média, para estender e desfocar a noção de moderno/modernidade, que a meu ver remete ao lluminismo, à Revolução Francesa, ao momento em que se abria um futuro sem fundamentação em qualquer experiência passada, em que se lançava uma flecha e não se sabia onde ela atingiria. Poderíamos, quiçá, voltar ao Renascimento, no caso aos Descobrimentos. Digo isso em função de algo que li recentemente sobre a Viagem de Colombo e Cabral e que buscava entender a sua novidade. O ponto era que partiam, pela primeira vez, em direção ao desconhecido, ou seja, iam com mantimentos e estrutura insuficientes para assegurar um retorno, partiam experimentalmente em busca do novo e só chegando aí haveria a possibilidade de uma volta. Isto para mim é o moderno, ter esta abertura para o novo, viver em nome da sua possibilidade. Esta também é a minha pergunta: acreditamos ainda no novo? Em parte empenho-me em 
acreditar que o novo ainda é uma questão, mesmo que se apresente de uma maneira diferente daquela do modernismo histórico, ou do vanguardismo, em que havia um novo impositivo cuja instauração determinava o inatual, o não-contemporâneo, o anacrônico. O que fico imaginando é a possibilidade de um outro novo, contemporâneo, que se dê pelo deslocamento e reinvenção do que já foi de outra maneira e não pela criação de algo que nunca teria sido.

Isto já estava dado, por exemplo, no Romantismo. Mais do que a tradição do novo o que singularizou aquele momento foi a afirmação de uma novidade da tradição. O Rancière aponta isto bem dizendo que mais do que inventar algo novo, eles, os Românticos, queriam inventar uma outra arte grega ou mesmo um novo Shakespeare. Outra razão que me obriga a afirmar a possibilidade do novo no contemporâneo é o meu arrepio diante dos anticontemporâneos que se dizem "nostálgicos do moderno", que afirmam justamente que o contemporâneo é a repetição do que já foi, ou então dos niilistas, que dizem que vivemos a época do valetudo e que querem a restauração da ordem. NÃO. Temos que ser abertos para o contemporâneo, acreditar na sua novidade, na sua atualidade, na sua experimentalidade e isso me parece ainda vinculado à dissolução referencial do moderno.

Outro ponto que me parece bacana no Rancière é quando ele desloca a questão modernidade/pós-modernidade para incluí-los dentro do mesmo regime estético (que no fundo, é moderno) e que tem justamente como ponto originário algo próximo do que você chama de condição experimental da arte e que eu chamo de instabilidade ontológica da arte. É claro que isso tem uma inflexão radical no Duchamp (e não nos anos de 1960 como faz crer o Danto e que às vezes sinto também na sua análise). Mas para isto surgir no Duchamp e no ready made, para que algo tão inusitado pudesse ser visto, mesmo enquanto mera possibilidade, como arte, teve que haver uma torção anterior, que remete ainda aos gêneros tradicionais, à pintura de cavalete, só que realizada de tal modo que rompia com seus procedimentos instituídos, suas expectativas de sentido, seus temas tradicionais. O Courbet me parece mais importante do que o Manet aí, pois é o primeiro a escrever um manifesto, apostando no que deveria ser arte (e que não era até então) e, logo depois, realiza uma exposição paralela e independente ao salão universal de 1855 , uma vez que fora por ele recusado, mobilizando o público para avaliar se suas pinturas eram ou não arte (segundo os critérios da Academia, não seriam, mas para o público que a visitara, sim). Dali para a criação do salão de recusados pelo imperador em 1863 foi um pulo, e o cisma quanto à condição de arte, estabelecido. Sem isso, não se pode chegar ao Duchamp.

Indo um pouco mais além e tentando voltar ao momento inaugural deste regime estético, retornaria a Kant, pois já estava inscrito na sua estética que o que define a singularidade do belo não é um modo de fazer, nem uma delimitação temática, mas um tipo de sentir, uma qualidade, uma tonalidade afetiva, que aviva a alma e sinaliza para uma comunidade de sentido; acrescenta-se a isto que qualquer um é capaz de ajuizamento 
estético, não há conceitos nem valores que determinam um modo de julgar - na pretensão de universalidade, lida como possibilidade de arte, de tornar-se arte, para ler duchampianamente, instaura-se a dimensão política, experimental, instável e moderna da arte contemporânea.

Nossa, escrevi muita coisa ao mesmo tempo, isto tudo deve ser mais bem analisado e separado. Já cansei por ora e creio que minha defesa do moderno não é habermasiana e faço coro com o próprio Lyotard, que disse: "reescrever a Modernidade é resistir à escrita dessa suposta pós-modernidade". Sei também dos riscos desta posição, primeiro por poder parecer fechado à diferença do contemporâneo; segundo, na medida em que trago para perto aliados perigosos. Mas vale a discussão e o esforço por se tentar fazer compreender.

Resposta de Virginia

\section{Oi Camillo}

Adorei seu livrinho sobre a Crítica!

Acho que concordo integralmente com ele. E gosto muito da apropriação que você fez de Kant.

Meu trabalho tem uma profunda afinidade com o seu. A prova é que tive, por diversas vezes, durante a leitura do livro, aquela sensação de que poderia estar escrevendo as mesmas palavras e frases que estava lendo. Também eu me preocupo com essa "atualização" da crítica de Kant... Até nos mínimos detalhes (por exemplo, quando você faz uma passagem pelo livro de Heidegger sobre Nietzsche, sobre o equívoco da recepção da tese do desinteresse...) Foram exatamente os mesmos caminhos que tomei... Você deve saber o quanto os kantianos dão pouca atenção a Heidegger e, no entanto, há naqueles brevíssimos parágrafos do seminário sobre Nietzsche uma importante contribuição, à qual você também foi sensível... Gostaria de pesquisar um pouco mais, mas tenho a impressão de que o século XIX não deu muita importância à Estética de Kant justamente por causa daquele equívoco nietzscheano. É mais do que provável que Nietzsche "desse as cartas" do pensamento filosófico sobre a arte. E como ele não compreendeu direito Kant, é normal que ele tenha orientado toda a filosofia da arte do seu tempo para uma direção diferente, senão mesmo oposta a Kant... É muito provável que sejam aqueles brevíssimos parágrafos de Heidegger que tenham chamado atenção (século XX) para a terceira Crítica de Kant. Certamente, como reconhece, mais uma vez, o próprio Heidegger, Kant teve uma recepção imediata que foi a de Schiller. Mas, por exemplo, qual a influência de Kant sobre um crítico de artes típico do século XIX, como Baudelaire? Creio que nenhuma! Então, fui lendo e concordando com praticamente tudo o que você escreveu. 
Interessou-me, sobretudo, essa intrínseca (afinal) relação entre liberdade e desorientação, que é tão característica de nossa época e de quanto a crítica se torna urgente e absolutamente necessária. A dificuldade de lidar com tamanha liberdade não afeta apenas o artista, mas também o espectador... Será que podemos afirmar que o espectador ideal da arte é o crítico? Será uma tese óbvia? Qual a diferença entre o especialista e o chamado "público em geral"? Será apenas uma diferença de grau de saber? Um sabe, conhece mais (história da arte, por exemplo)? São as questões de sempre, que permanecem não respondidas, mas que temos a obrigação de colocar, não? Uma das ideias do seu livro que mais repercute em mim, a qual eu já tinha referido na minha palestra lá na PUC, é a de que "julgar é produzir diferenças". Precisamos retirar aquele sentido jurídico de "condenação" ou mesmo "veredicto" do termo "juízo"... É muito difícil distanciar a verdade do jurídico, como muito bem sabia Foucault... Reivindicar um estatuto de verdade para a arte que não tenha essa conotação jurídica não me parece uma operação muito simples! Daí por que a ideia de "produzir diferenças" me parece bem interessante, mesmo que não saiba totalmente o que você quis dizer com isso, a sua formulação me "agrada" muito.

Gostaria de saber mais sobre Goodman - nunca li nada! - para compreender a sua proposta de deslocar a questão "o que é arte?" para o "Quando é arte?"... Eu ainda continuo "fiel" à tese "deduviana", digamos assim, da mudança da questão "isto é belo" para a pergunta "isto é arte?"

Um grande abraço e parabéns mais uma vez pelo belo [o belo ainda terá atualidade? Por que não? Irrita-me um pouco a obstinada predileção pelo feio da arte contemporânea... Bem, reconheço que há muitos problemas aí... Talvez, um inconfessado, tradicional e conservador classicismo do (meu) gosto] livro!

Virginia

\section{*Virgínia Figueiredo é professora do Departamento de Filosofia da UFMG.}

${ }^{1}$ HÖLDERLIN, F. Carta a Böhlendorf, de 4 de dezembro de 1801. In: Reflexões. Tradução de Márcia de Sá Cavalcante. Organização de Antônio Abranches, Rio de Janeiro: Relume-Dumará, 1994, p. 132.

${ }^{2}$ Devo confessar que não tive tempo de ler o livro de Nicolas Bourriaud. Suponho que seja no Esthétique Relationnel, onde ele desenvolva o conceito de "altermodernidade"?

${ }^{3}$ Devo a expressão a Arthur Grupillo Chagas, ex-aluno de Doutorado do Programa de PósGraduação em Filosofia da UFMG, a quem aproveito para agradecer aqui.

${ }^{4}$ La condition postmoderne, como todo mundo sabe, é um livro de Jean-François Lyotard, publicado em 1979 que analisa a cultura da pós-modernidade como sendo a do fim das grandes (ou meta) narrativas, consideradas por Lyotard como a essência da Modernidade. O texto foi um "escrito de circunstância", como nos informa a Introdução à tradução brasileira ( $A$ condição pós- 
moderna. Tradução de Ricardo Barbosa. Rio de Janeiro: José Olympio, 1998, p. XVII) e pretendia ser apenas um Relatório ou "exposição sobre o saber nas sociedades mais desenvolvidas, proposto ao Conselho das Universidades junto ao governo de Quebec" (ibidem) Lyotard introduz na Filosofia o termo "Pós-moderno" que já era utilizado "no continente americano, por sociólogos e críticos" (p. XV), definindo: "'pós-moderna' [é] a incredulidade em relação aos metarrelatos" (p. $\mathrm{XVI})$.

Não se trata aqui de discutir a recepção do livro de Lyotard. Mas, não posso reprimir o comentário de que tudo não passou de um imenso mal-entendido. Ora, Lyotard está a léguas de uma posição apologética da "condição pós-moderna"... A anatomia que faz da nossa época é, ao contrário, muito próxima da crítica, e até de uma "amarga crítica". Trata-se antes de uma descrição pessimista da situação do saber no capitalismo avançado. Como diz Italo Moriconi na orelha do livro: "Lyotard nunca foi um apologeta da pós-modernidade. Pelo contrário, tornou-se um de seus mais furiosos críticos, no campo das questões estéticas. Em A condição pós-moderna, Lyotard pretendeu expor, de maneira basicamente descritiva, os pressupostos objetivos que permitiam falar de uma transformação radical da maneira como o saber é produzido, distribuído e principalmente legitimado, nas áreas mais avançadas do capitalismo contemporâneo. Daí a centralidade do termo condição. Um termo filosoficamente nada ingênuo, que opera uma fusão específica entre elementos de kantismo e de marxismo. Lyotard sempre foi o mais eclético dos filósofos de 68. Mas o que emerge destas páginas seminais, muito além dos criticismos kantiano e marxista, é o ponto de vista cético e pragmático que acabou por dominar boa parte do pensamento ocidental nos últimos anos. Em $A$ condição pós-moderna, tal ponto de vista se traduz na famosa tese do fim das metanarrativas de legitimação do saber e da política [grifo meu], que significa a perda de atração pelos ideais altissonantes da modernidade clássica. A versão lyotardiana do pragmatismo contemporâneo, porém, nada tinha de conformista ou liberal. Ao propor o que chamou de uma agonística geral dos discursos, Lyotard permaneceu fiel a seu passado militante, tanto neste quanto em todos os seus livros".

${ }^{5} \mathrm{O}$ pretexto dessa correspondência (iniciada em 2008 e logo interrompida, infelizmente) foi o texto "O Moderno depois do Modernismo" que Luiz Camillo Osório escrevera para um Seminário realizado pelos 60 anos do MAM-SP. Resolvemos acrescentar como anexo, ao final desses textos mais recentes (2012), uma parte dessa correspondência de 2008 que versava, coincidentemente, sobre o mesmo tema.

${ }^{6}$ Eu fazia (faço ainda hoje) questão de diferenciar a sua perspectiva, por isso a chamava de conceito "ampliado" ou "hipertrofiado" de modernidade, daquela de Habermas que afirmava estar ainda "inacabado" o projeto da modernidade...

${ }^{7}$ KANT, I., Jäsche Logik, AA, 09: pp. 88-89. Lógica. Tradução de Guido Antônio de Almeida. Rio de Janeiro: Tempo Brasileiro, 1992, p. 109.

${ }^{8}$ KAPROW, A., "O legado de Jackson Pollock". In: FERREIRA, G.; COTRIM, C. (orgs.) Escritos de Artistas. Rio de Janeiro: Jorge Zahar, 2006, p. 44. Após descrever maravilhosamente o movimento (evolução) da pintura como o de uma crescente projeção de dentro para fora do quadro, Kaprow conclui: "Objetos de todos os tipos são materiais para a nova arte: tinta, cadeiras, comida, luzes elétricas e néon, fumaça, água, meias velhas, um cachorro, filmes, mil outras coisas que serão descobertas pela geração atual de artistas. Esses corajosos criadores não só vão nos mostrar, como que pela primeira vez, o mundo que sempre tivemos em torno de nós mas ignoramos, como também vão descortinar acontecimentos e eventos inauditos, encontrados em latas de lixo, arquivos policiais e saguões de hotel; vistos em vitrines de lojas ou nas ruas; e percebidos em sonhos e acidentes horríveis. Um odor de morangos amassados, uma carta de um amigo ou um cartaz anunciando a venda de Drano; três batidas na porta da frente, um arranhão, um suspiro, ou uma voz lendo infinitamente, um flash ofuscante em staccato, um chapéu de jogador de boliche tudo vai se tornar material para essa nova arte concreta. [...] Jovens artistas de hoje não precisam mais dizer 'Eu sou um pintor' ou 'um poeta' ou 'um dançarino'. Eles são simplesmente 'artistas'. Tudo na vida estará aberto para eles. Descobrirão, a partir das coisas ordinárias, o sentido de ser ordinário. Não tentarão torná-las extraordinárias, mas vão somente exprimir o seu significado real. 
No entanto, a partir do nada, vão inventar o extraordinário e então talvez também inventem o nada. As pessoas ficarão deliciadas ou horrorizadas, os críticos ficarão confusos ou entretidos, mas esses serão, tenho certeza, os alquimistas dos anos 60".

${ }^{9}$ Diferentemente do sentido estritamente kantiano de liberdade moral, i.e., daquela liberdade racional que pode, se for necessário, «humilhar» a sensibilidade, para Schiller, ser livre significa as faculdades se estimularem num jogo nunca repressivo.

10 «Ousar saber» (ou «ter coragem de fazer uso do próprio entendimento»), como todos sabem, constitui o lema do Esclarecimento [Aufklärung] que é, por sua vez, «a saída do homem de sua menoridade». É assim como Kant começa sua famosíssima «Resposta à Pergunta: que é 'Esclarecimento'?». Tradução de Floriano de Sousa Fernandes. In: Immanuel Kant, textos seletos. Organização e introdução de E. Carneiro Leão. Petrópolis: Vozes, 1974, p.100. Devo parte desse desenvolvimento às sugestões que me fizeram os alunos bolsistas de Iniciação Científica Hudson Assis e Regina Sanches, a quem aproveito para agradecer aqui.

${ }^{11}$ OSORIO, L. C. "Para que arte e para que crítica? Encontros e Desencontros". In: LOPES, A.; PESSOA, F. (orgs.) Arte em tempo indigente. Vila Velha: Museu Vale, 2008, p. 193. Repito aqui a mesma citação que fiz: FIGUEIREDO, V. "Kant e a arte contemporânea". In: Especiaria Cadernos de Ciências Humanas, v. 11, n. 19 (jan-jun, 2008), p. 26.

${ }^{12}$ KANT, I. Kritik der Urteilskraft. Crítica da faculdade do juízo. Tradução de Valério Rohden e Antonio Marques. Rio de Janeiro: Forense Universitária, 2010. KANT, I., AA, 05: 158, CFJ, p. 140.

${ }^{13}$ ARENDT, H. Lectures on Kant's Political Philosophy. Organização de Ronald Biener. Chicago: University of Chicago Press, 1982; Lições sobre a filosofia política de Kant. Tradução de André Duarte. Rio de Janeiro: Relume-Dumará, 1993. Na verdade, Arendt prefere o termo «generalidade» ao invés de «universalidade», mas não creio prejudicar sua interpretação se dela me aproprio com outro nome mais adequado à nossa discussão.

${ }^{14}$ Cf. SÜSSEKIND, P. Shakespeare, o gênio original. Rio de Janeiro: Jorge Zahar, 2008, p. 75: «Para [Victor] Hugo, enquanto Homero marca, na Antigüidade, o fim da Ásia e o começo da Europa, Shakespeare marca o fim da Idade Média e a força criativa que surge num momento crítico para a humanidade, inaugurando a época moderna.» Shakespeare é o gênio moderno por excelência é a tese subjacente do livro de Süssekind.

${ }^{15}$ Foi um tema recorrente, uma espécie de leitmotif, na obra de Hannah Arendt a frase de Tocqueville "Desde que o passado deixou de lançar sua luz sobre o futuro, a mente do homem vagueia nas trevas." (ARENDT, H. "Prefácio: a quebra entre o passado e o futuro". In: Entre o Passado e o Futuro. Tradução de Mauro Barbosa de Almeida. São Paulo: Ed. Perspectiva, 2000, p. 32) E era com muita melancolia que constatava que o sentido da ação sempre escapa aos vivos; eles não sabem sequer dar os nomes, por isso perdem o próprio tesouro que possuíam. (cf. EPF, p. 31)

${ }^{16}$ Afinal, será esse o sentido de "altermodernidade"?

17 Conforme observou Ronald Beiner ("Interpretative Essay". In: Lectures on Kant's Political Philosophy. Chicago: Chicago University, 1982. p.138): "The attempt to transpose a theory of judging as formal as Kant's into a theory of political judgment runs the risk of turning from a genuine appreciation of political appearances qua appearances into an unwarranted aestheticization of politics". [A tentativa de transpor um teoria do juízo tão formal como a deKant numa teoria do juízo político corre o risco de transformar-se de umaconsideração genuína dos fenômenos políticos qua fenômenos numa injustificada estetização do político].

18 Retomo a partir daqui alguns parágrafos de um ensaio que publiquei em inglês («The immanence of politics in Kant's Aesthetics») nas Atas do X Congresso Internacional Kant. Recht und Frieden in der Philosophie Kants, v. 3. Organização de Valério Rohden, Ricardo Terra et al., New York, Berlin: Walter de Gruyter, 2008, pp. 586-587. 
${ }^{19}$ Menciono aqui o exemplo da Revolução Francesa somente para seguir Arendt que comentou extensa e famosamente o entusiasmo com o qual Kant "recebeu" a Revolução Francesa.

${ }^{20}$ Cf. FIGUEIREDO, V. «A permanência do trágico» In: ALVES JR., D. G. (org.) Os destinos do trágico. Belo Horizonte: Autêntica/FUMEC, 2007, pp. 54-57.

${ }^{21}$ ALLEMANN, B. "Hölderlin entre les Anciens et les Modernes". In: Cahiers de I'Herne, Hölderlin. Paris: Ed. De I’Herne, 1989, p 309.

${ }^{22}$ LACOUE-LABARTHE, P. "Hölderlin e os Gregos". In: A imitação dos modernos. Op. cit., p. 218.

${ }^{23}$ É possível que o ensaio de Walter Benjamin "Dois poemas de Friedrich Hölderlin" (1914-1915) tenha inaugurado aquela apreensão filosófica da obra de Hölderlin. Os artigos de Heidegger sobre o poeta datam de 1935-36 mas, como é sabido, o texto de Benjamin permaneceu inédito até 1955, quando Adorno e Scholem publicaram a primeira coletânea de ensaios dispersos de Benjamin. (Cf. LACOUE-LABARTHE, P., "A coragem da poesia" In: A imitação dos modernos, Op. cit., p. 285).

${ }^{24}$ cf. LACOUE-LABARTHE, P. "A cesura do especulativo". In: A imitação dos modernos. Op. cit.,. pp. 181-209.

${ }^{25}$ Talvez a normalmente obscura noção heideggeriana de "historial" possa afinal ser explicada pela reflexão poético-histórica de Hölderlin.

26 Gostaria aqui de enfatizar essa diferença que considero marcante dentro das diversas interpretações da obra de Hölderlin que conheço. Trata-se da necessidade de não reduzir a abordagem histórico-poética de Hölderlin à concepção dialética de Hegel da história. Parafraseando o título do ensaio labarthiano, tratar-se-ia de suspender o dialético dentro do especulativo. Então, se autores como Lacoue-Labarthe e Beda Allemann, cujas leituras estou filiando à heideggeriana, as quais, exatamente por causa dessa herança, estão super atentos àquela diferença entre Hölderlin e o grande monstro da dialética moderna que é Hegel, o mesmo não ocorre com outras leituras, também atentas à filosofia hölderliniana da história, como, por exemplo, são as de Peter Szondi e de Jacques Taminiaux. Esses, incapazes de operar com a noção mimetológica (esse é o conceito que devemos guardar) de história em Hölderlin, quando precisam dividir a obra poética que, com razão eles percebem, abriga, pelo menos, duas concepções do trágico, são obrigados a apelar para critérios externos. No caso de Jacques Taminiaux, ele recorre a um critério, no mínimo obscuro, que consiste em atribuir "graus metafísicos". Então, haveria um primeiro conceito de trágico "mais metafísico" e que se encarnaria no Empédocles, obra que Hölderlin estava tentando escrever durante o período entre1798-1800; e um segundo, "mais prático e ético", encarnado nas traduções de Sófocles, publicadas em 1804, nas quais Hölderlin teria assumido até as últimas conseqüências o ensinamento da Poética de Aristóteles. (cf. Le Théâtre des Philosophes). Já para Peter Szondi, as duas concepções do trágico em Hölderlin seriam formuladas justamente como dialéticas, mudando apenas a direção, de uma para outra: a primeira concepção do trágico consistiria numa dialética horizontal entre arte e natureza e a segunda, numa dialética vertical entre mortais e divinos. (cf. «Le concept du tragique chez Schelling, Hölderlin et Hegel». In: Poésie et poétique de I'Idéalisme Allemand).

${ }^{27}$ LACOUE-LABARTHE, P. "Hölderlin e os Gregos". In: A imitação dos modernos. Op. cit., p. 220.

${ }^{28}$ Ibidem, p. 218.

${ }^{29}$ ANDRADE, M. apud MORAES, E.J. Os limites do Moderno - o pensamento estético de Mário de Andrade. Rio de Janeiro: Relume-Dumará, 1999, p. 30.

${ }^{30}$ HEINE, H. Prosa política e filosófica apud ALMEIDA, J., «Introdução». In: ALMEIDA, J.; BADER, W. (orgs.) Pensamento alemão no século XX, vol. I. São Paulo: Cosac Naify, 2009, p. 17.

${ }^{31}$ Ibidem, p. 21. 
32 Repetindo nota anterior: o pretexto dessa correspondência (iniciada em 2008 e logo interrompida, infelizmente) foi o texto "O Moderno depois do Modernismo" que Luiz Camillo Osório escrevera para um Seminário realizado pelos 60 anos do MAM-SP.

${ }^{33}$ VAZ, H. C. de L. Raízes da Modernidade. Escritos de filosofia VI. São Paulo: Loyola, 2002.

${ }^{34}$ SOURIAU, E. Verbete "Moderne/Modernité". In: Vocabulaire d'esthétique, Paris: Quadrige/PUF, 1990.

${ }^{35}$ VAZ, H. C. de L. Escritos de filosofia III. Filosofia e cultura. São Paulo: Loyola, 1997, p. 226.

${ }^{36}$ Ibidem, p. 225.

${ }^{37}$ HABERMAS, J. O discurso filosófico da Modernidade. Tradução de Luiz Sérgio Repa e Rodnei Nascimento. São Paulo: Martins Fontes, 2002. Como se sabe, em doze Lições, como ele mesmo subintitulou, Habermas passa em revista várias etapas da construção desse conceito filosófico por natureza que é a Modernidade: de Schiller a Derrida, passando por Hegel, Weber, Adorno, Heidegger, Bataille, Foucault (a lista é realmente imensa).... A partir daqui, utilizo a abreviação DFM.

${ }^{38}$ Ibidem, p. 3.

39 Ibidem, p. 9.

${ }^{40}$ Ibidem, p. 15.

${ }^{41}$ Ibidem, p. 17.

${ }^{42}$ Ibidem, p. 121.

43 Ibidem, p. 2.

${ }^{44}$ Ibidem, p. 142. Se fosse assim, como compreenderíamos o elogio que Heidegger faz a Paul Celan, que nunca foi um exemplo de artista clássico? O único fato pelo qual, talvez, se possa condenar Heidegger foi de ele jamais ter se dedicado às outras artes (como a música ou a pintura), além da literatura (seria até mais exato dizer: além da poesia)... Mas, será mesmo isso condenável? O que é inaceitável é afirmar que Heidegger "como Hegel [...], está convencido de que a arte chegou ao seu fim essencial com o Romantismo"!!! (p. 143) Isso é exemplo de uma leitura pouco atenta. Bastaria a Habermas ter lido as poucas linhas do Posfácio do ensaio sobre a "Origem da obra de arte" para desfazer seu preconceito. Ali, apesar de levar em conta (seriamente) a tese hegeliana do "fim da arte" [Já estavam nos Seminários sobre Nietzsche as seguintes palavras que Heidegger repete naquele Posfácio: "as Preleções sobre estética são a mais abrangente reflexão que o Ocidente possui sobre a essência da arte - porque pensada a partir da Metafísica"], Heidegger se confronta com ela e dela discorda. De modo sucinto, se Hegel acredita ser um progresso do Espírito Absoluto o momento no qual "discurso filosófico sobre a arte" (i.e., a Estética) supera [aufheben] a própria arte, na medida em que a Filosofia seria um discurso "mais avançado" em termos de "racionalidade", pois perderia o elo com a sensibilidade que toda arte inevitavelmente contém; para Heidegger, precavido contra os elos entre a Estética e Metafísica, e, além disso, crítico atroz deste acontecimento moderno da história da Filosofia, que é o "aparecimento da subjetividade", jamais pôde se conformar com a redução da arte à esfera da fruição e do sentimento estéticos... Heidegger queria resgatar um sentido histórico e político que a arte perdera desde a sua "entrada no horizonte da Estética" [HEIDEGGER, M. "Die Zeit des Weltbildes" In: Holzwege, p. 69, apud NUNES, B. "A poética do pensamento" In: NOVAES, A. (org.) Artepensamento São Paulo: Cia. das letras, 1994, p. 397]. Assim, a meu ver, ao invés de concordar com Hegel (como Habermas quer nos fazer crer) sobre o Fim da Arte e Progresso da Estética, Heidegger estaria tentando uma operação muito mais complexa (ou talvez, simplesmente oposta: Fim da Estética e Recomeço da Arte), que eu designaria como uma "libertação" da arte do domínio da Estética. Poderíamos também denominar o Programa heideggeriano (oposto ao de Hegel) de "Desestetização da arte". 
${ }^{45}$ Ibidem, p. 143. Mas, prometo ficar por aqui com a polêmica Habermas $x$ Heidegger. Seria muito longo desconstruir passo a passo o equívoco, a meu ver, da interpretação habermasiana do pensamento de Heidegger.

${ }^{46}$ HEIDEGGER, M., Introdução à metafísica. TradUção de E. Carneiro Leão. Rio de Janeiro: Tempo Brasileiro, 1987, p. 151.

47 Com muita razão, alguém poderá objetar que o princípio da experimentação proposto por Lyotard como fundamento da arte contemporânea não se contrapõe de maneira alguma à característica mais importante do gênio que é a originalidade.

${ }^{48}$ É claro que não há espaço aqui para explorar os caminhos da mimetologia lacoue-labarthiana que nos propõe uma releitura revigorante desse importante conceito estético: mimesis.

${ }^{49}$ Com certeza não foi Danto que enunciou originalmente essa tese. Conceda-se a ele pelo menos o fato de haver enfatizado esse problema (como a característica talvez essencial da arte moderna e contemporânea) que ele compartilha com muitos outros filósofos da arte. Só para citar alguns: Adorno, W. Benjamin, Heidegger.

${ }^{50}$ Seria ainda moderna - ou exclusivamente contemporânea - a arte da qual Danto está falando? Não nos esqueçamos que a famosa Fountain é de $1917 \ldots$ 